\title{
Production Waste from Hard Coal Mining in the Light of Circular Economy
}

\section{Katarzyna TOBÓR-OSADNIK ${ }^{1)}$, Małgorzata WYGANOWSKA ${ }^{2)}$, Barbara KOWAL ${ }^{3)}$}

\footnotetext{
${ }^{1)}$ Ph.D., DSc, Eng.; Silesian University of Technology, Gliwice, Poland; email: katarzyna.tobor-osadnik@polsl.pl

2) Ph.D., DSc, Eng.; Silesian University of Technology, Gliwice, Poland; email: malgorzata.wyganowska@polsl.pl

3) Ph.D., DSc, Eng.; AGH University of Science and Technology, Cracow, Poland; email: bkowal@agh.edu.pl
}

http://doi.org/10.29227/IM-2020-01-78

Submission date: 19-11-2019 | Review date: 03-01-2020

Abstract
Mining plants are faced with the task of seeking image change with a positive economic result. Post-mining waste may be an opportu-
nity for mining enterprises to implement the circular economy idea. In this article, the authors presented an overview of some of the
most important waste, such as dumps, methane or mine waters. The analysis of the composition of brines obtained in the "Dębiens-
ko" Plant allowed the authors to formulate numerous conclusions for their new use. Air pollution and, at the same time, increased
health-related needs of society open new opportunities for pro-ecological and recreational use of what has constituted the negative
perception of the hard coal industry in Upper Silesia. The article proposes a number of solutions in this area.

Keywords: coal mining, wastes, slagheaps, saline, methane

\section{Introduction}

Everybody got used to treat mines on Upper Silesia as „manufacturer” of hard coal and numerous group of by-production waste. Modern player on the market primo cannot therefore barrow his offer to only one product, secondo perhaps he should use maximally all production materials. To produce by-production waste belongs among all others rock wastes which are stored on coal spoil - heap, methane from current exploitation from operating mines and also from already closed mines, and also salted mining waters. Those products were problem until now and were treated as waste, but directions of diversification of actions in managing of polish mining of hard coal allowed to see a chance for using them and modifying in new commercial product. It was patterned on currently existing similar solutions from country and abroad. In this article Authoress show already realized projects and project proposals of by - products management of hard coal exploitation in Poland. Projects already realized are: gaining and using of methane from hard coal mines, utilization and management coal spoil - heap for various purposes, and the proposal of Authoress is to use saline which occurs while desalting of mine water in Desalting Plant „Dębieńsko” for recreation and healing purposes (Fig.1.).

\section{Slagheaps of post-mine waste}

Element of Silesian scenery are slagheaps of post-mine waste. They consist of vary types of rock material, mostly coming from hard coal mines, but also from foundries, power plants and thermal power plant. For all inhabitants they are very arduous in many aspects: they are chemically and thermal active, they dust. Their influence on environment can manifest itself in soil degradation, penetration of chemical ingredients into underground and superficial water [1,2]. Slagheaps have tendency to self-ignition, what causes emanation of oxide and dioxide of carbon and sulphur compound to the atmosphere. Most famous are: slagheap in Rydułtowy „Szarlota” and slagheap „Skalny” in Łaziska Górne.

Slagheap in Rydułtowy is one of the highest slagheaps in Europe - from the base is about $134 \mathrm{~m}$, top is on $407 \mathrm{~m}$ above sea level, it's area is 37 hectares and volume 13,3 million $\mathrm{m}^{3}$. In 2007 it was named Szarlota and this name was put on the top, referring to Hollywood inscription. Partly it is covered with vegetation, but is important part of the whole scenery. From its top mountains on the Czech side can be seen [3].

Slagheap „Skalny” w Łaziska Górne is placed on $389 \mathrm{~m}$ above sea level and is on 30 ha. Weight of rock material which is inside of it is estimated on 17 million ton. It is one of the biggest in Europe. Post-mine waste on "Skalny” is being gathered from over 220 years. Big problem on this slagheap was self-ignition. During this to the atmosphere compounded carbon oxide, sulphure dioxide and nitrogen oxide. Big ardous for the inhabitants was very bad small. On the slang-heap was introduced innovative method which included using liquids from Thermal Power Plant Łaziska $[4,5]$. Currently slagheap area is grassed, and on its top there is lovely lake. Although officially it is not yet allowed to use this new green area, slagheap is target for many Sunday walks.

Interesting management of post-mining dumping ground was initiative of revitalization of after mining areas in Bieruń Nowy. Although investment of creating recreation centre for the city and surroundings wasn't finished, but area has been shaped and planted round. For further works influenced economic situation of the commune.

In 2005 conversations have been started and developed interesting plans of management slagheap Maria in Murcki (Fig. 2.) There were supposed to be created two artificial ski slopes and artificial chutes. Historical buildings of the mine were supposed to be transformed into hotel, spa and covered swimming pool, playing ground, bowls and stable. This project took second place in competition „Technośląsk” for managing of post-industrial area. 


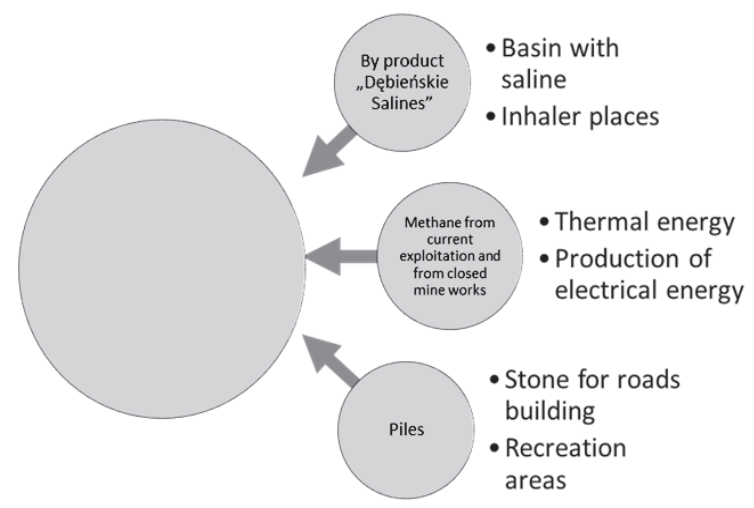

Fig. 1. Directions of using some of by-products while exploitation of hard coal in Poland. Source: own study Rys. 1. Kierunki wykorzystania produktów ubocznych eksploatacji węgla kamiennego. Źródło: opracowanie własne

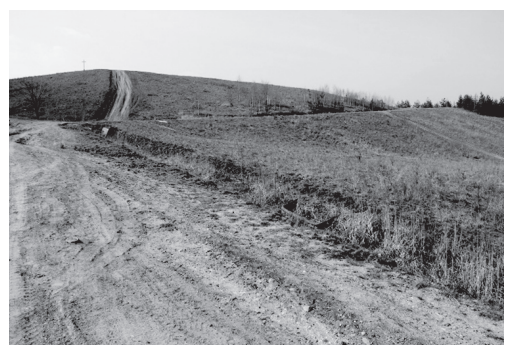

Fig. 2. Reclaimed slagheap Maria in Murcki [Przemysław Kucharczak's foto] Rys. 2. Zrekultywowana hałda Maria w Murckach [Zdjęcie Przemysław Kucharczak]

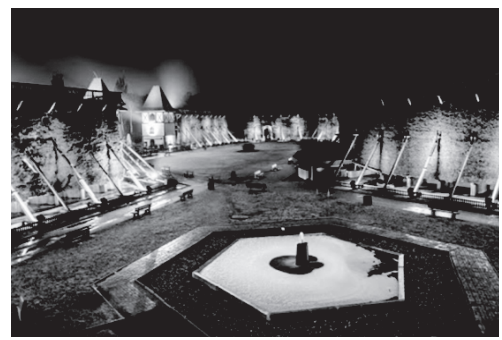

Fig. 3. Saline graduation tower and fountain in Inowrocław [21]

Rys. 3. Tężnia i fontanna solankowa w Inowrocławiu [21]

Similar project was developed for slagheap in commune Moszna with cooperation of Jastrzębska Spółka Węglowa Co. Unfortunately for now on commune is planning to create on the area of slagheap motocross race tracks and preparing more convenient conditions for paragliding which is developing there [6]. Alike project was used for slagheaps in surroundings of Wałbrzych. Local Automobilclub is organizing periodical races „Hałda”. It is important event in the environment of sport drivers. Also elimination for Europe championship in competition „Europe Truck Trial” took place over there. In 2008 were organized Polish Race Champioships Off -road Cars.

Interesting undertaking of creating recreation and relaxation center Dolomity Sportowa Dolina in Sucha Góra which was created on the basis of post-mining excavation by adapting areas of old open-cast mine. This center offers two ski slopes, one snowboard, bicycle and walk routes, in the future tennis court and pools. Similar center was established in Sosnowiec.

It is worth to mention about the biggest managing post-mining areas which is Provincial Park of Culture and
Rest in Chorzów (WPKiW). It was established on the areas of many poverty pit-shafts, mining subsidence, mines and metallurgical slagheaps. In the center of industrial Silesia was created "green heart", which is serving and is being developed for its inhabitants.

To foreign examples of utilizing in the purpose of recreation, culture and recultivation post-mining slagheaps are slagheaps from the area of the Rurh in Germany, area of Nord-Pas de Calais in France and surroundings of Lille in United Kingdom. On their example were created landscape composition, ski centers, vantage points, and technological parks, innovative and interesting residential settlements. Such management of slagheaps is being axis around which are being established and developed small and middle city centers. Slagheap after transformation is being chance for developing of those areas [7].

Other direction for utilizing slagheaps is another exploration and taking advantage of material which is gathered there for road building, engineering and hydro technical works. Loams and loams slates which are stored there can be utilized in ceramic industry and for stoneware products. Carbonate 
Tab. 1.. The share of minerals in the compared salines. Source: own study based on [19] and Analiza fizyko-chemiczna solanki z odwiertu St-5 przeprowadzona w dniu 29/10/2014 przez Laboratorium Analiz Wód Głównego Instytutu Górnictwa [20]

Tab. 1. Udział składników mineralnych w porównywanych solankach. Źródło: opracowanie własne na podstawie [19] i Analiza fizyko-chemiczna solanki z odwiertu St-5 przeprowadzona w dniu 29/10/2014 przez Laboratorium Analiz Wód Głównego Instytutu Górnictwa [20]

\begin{tabular}{|l|l|l|}
\hline mentioned composition & $\begin{array}{l}\text { Dębieńsko salines } \\
\text { solid substances dissolved } \\
\text { in } \mathbf{1 ~ k g}[\%]\end{array}$ & $\begin{array}{l}\text { Zabłocka salines } \\
\text { solid substances dissolved } \\
\text { in 1 } \mathbf{~ k g}[\%]\end{array}$ \\
\hline solid substances & $30 \%$ & $3,80 \%$ \\
\hline iodides & $0,018 \%$ & $0,012 \%$ \\
\hline bromides & $0,10 \%$ & $0,016 \%$ \\
\hline chlorides & $16,00 \%$ & $2,30 \%$ \\
\hline magnesium & $2,50 \%$ & $0,05 \%$ \\
\hline potassium & $1,40 \%$ & $0,01 \%$ \\
\hline sodium & $5,00 \%$ & $1,31 \%$ \\
\hline
\end{tabular}

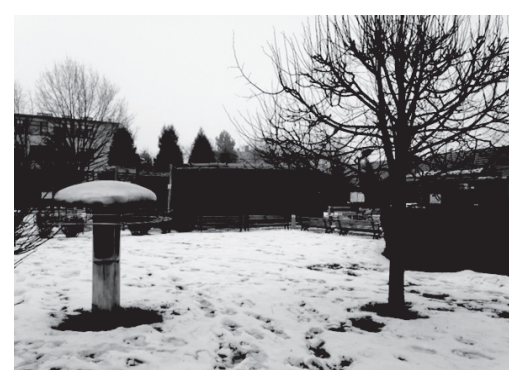

Fig. 4. Saline graduation tower and fountain in Dębowiec (K. Tobór-Osadnik`s foto) Rys. 4. Tężnia i fontanna solankowa w Dębowcu (zdjęcie K. Tobór-Osadnik)

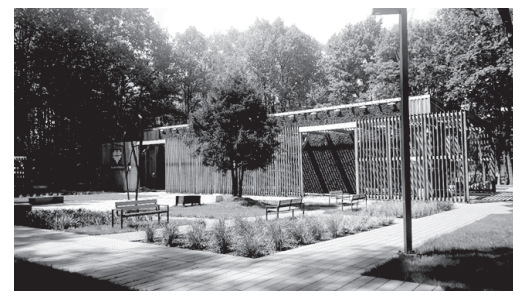

Fig. 5. Saline graduation tower in Katowice (K. Tobór-Osadnik`s foto) Rys. 5. Tężnia solankowa w Katowicach (zdjęcie K. Tobór-Osadnik)

rocks can be used for chemical fertilizers production, for bituminous mass, cement, technical chalk, broken aggregate and also in glass-sand industry [8].

Slagheaps on Silesia were arising since few hundreds of years and are part of Silesian landscape. But they are not sentenced for general ugliness and condemnation, but can be opportunity for different commune development and pride of inhabitants. They are source of economical and culture benefits of this region.

\section{Methan}

Next by-product while hard coal exploitation on Upper Silesia possible to be managed is methane. Methane is gas which accompany to coal deposits. Biggest technical and economical meaning has methane in taken by de-methane mines system. In exploited mines methane emits from excavation deposits and is being drained with the ventilation air (source of harmful emission) or is drained with de-methane systems (possible to energetic utilize). Not in every polish mines de-methane process is being conducted (or was conducted). From exploited deposits methane is mostly being drained off with ventilation air which also is very dangerous emission source [9]. Data are showing that only 30 percent of methane emitting while coal extraction is being captured in de-meth- ane installations and to economic usage is reaching less than $1 / 5$ of whole $[10,11]$. Additionally methane drained to atmosphere is charged for harmful substances emission. However, amended energetic law says that, energy seller will have to have in his offer energy from methane sources. It means that, similar as in energy from renewable sources producer of methane energy will be having incomes from energy sale and its certificates of origin. Methane can be chance for many communes [12]. They want to heat with it apartments and residential building. In Skoczów they want to buy methane from mine work Morcinek in Kaczyce, in Gierałtowice from mine work Budryk in Ornontowice [13]. Urban Enterprise of Thermal Energetic "Ciepło" in Skoczów is purchasing natural gas extracted by Enterprise of De-Methane Mines in Dębowiec, near Jaworzno. It is delivering heat to apartments on biggest housing estates of Skoczów. Infrastructure of gas system and relatively low possibilities of methane transport influence on way of managing gas from de-methane coal deposits.

Those are among others:

- Generating heat for heating and technological needs by gas combustion in boilre or technological installations (eg. Drying chamber),

- Associated generating of electrical energy and hot water, 


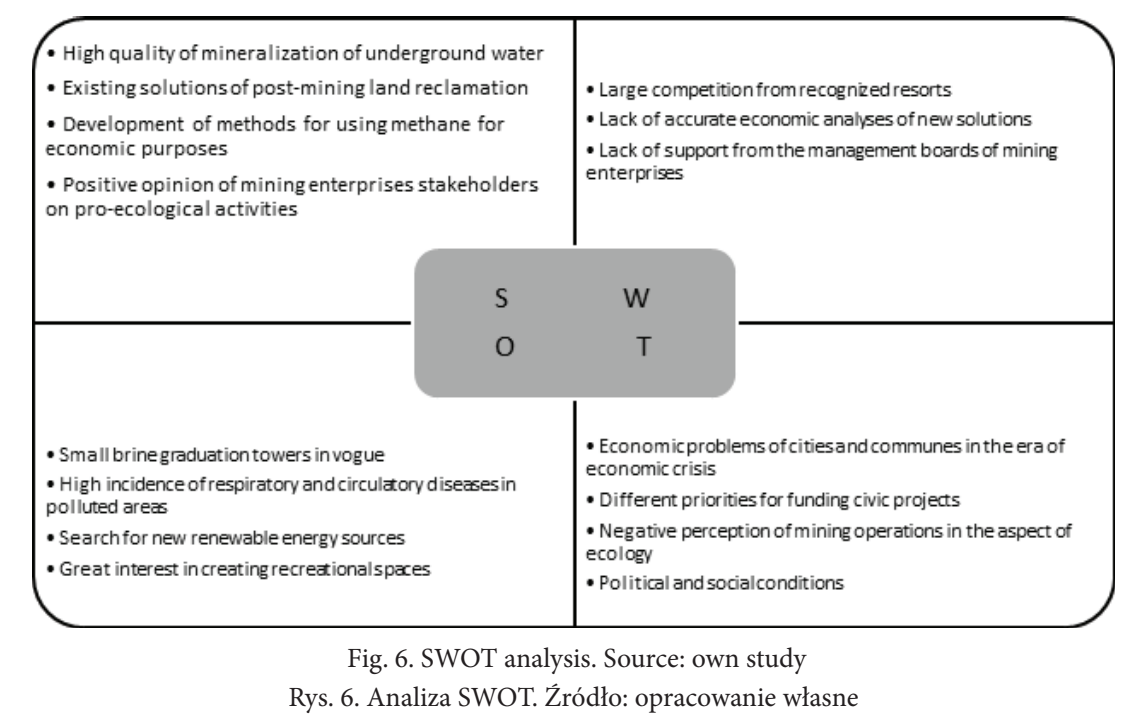

- Associated generating of electrical energy and technological vapour,

- Associated generating of electrical energy and factors for drying processes need,

- Associated generating of heat, cold and electrical energy generating of electrical energy in combined systems [14].

From polish hard coal mines is extracted 120 million $\mathrm{m}^{3}$ of methane yearly, from this 80 million $\mathrm{m}^{3}$ is evaporating to the atmosphere by mine ventilating systems and 30 million $\mathrm{m}^{3}$ is being caught and utilize [15]. More and more interest on new energy sources helps to look different on hard coal and for new opportunities of using it, but also utilizing chances of common occurring and possibilities of utilizing "exploited" methane [16].

\section{Salines}

The problem with saline mine waters is primarily related to environmental protection. Pouring underground water into rivers is a problem for people, fauna and flora in mining regions [17]. On Upper Silesia also occurs, next to other natural resources, relic waters of upper Carbon, which can be utilize for healing salts production, like it takes place for example in Dębowiec near Skoczów (Fig. 4.). It is great example of product, on one hand commercial and on the other hand geo-touristic one, because it is being used in saline fountain which attracts tourist and region inhabitants.

This inspired authors to pay attention to occurring possibilities of utilizing desalted deep waters. Saline which is created as by-product of deep waters desalting process in Dębieńsk has similar properties and chemical as saline from Dębowiec. Introduced analysis of Dębińska saline in National Institute of Hygiene (Państwowy Zakład Higieny) in Poznań in 1985 [18] indicates on its high therapeutic values; comparison of chemical composition with commonly used one in health medicine, for example in Ciechocinek and Inowrocław, indicates that the effect will be, if not the same, than very similar. Currently conversations with Inwrocław are conducted, which is interested in purchasing saline for therapy purposes.

According to conducted researches instructions for bath in diluted Dębieńska saline:

- Allergic diseases,

- Rheumatism diseases: among others rheumatoid arthritis, ankylosing arthritis of spine, states after operations, gouty arthropatry,

- arterial hypertension I/II and II period of disease,

- diseases of vessels of lower limbs with chronic ischemia,

- diseases of orthopedic - injury and states after operations of organs of motions, diseases of nervous system, among others: chronic inflammation of peripheral nerve, neuraligia, discopathy, hemiparesis, multiple sclerosis, neurosis.

Recommended is treatment of 10-20 minutes baths complete or partly, in diluted saline depending on age or state of progression of disease.

In 1985 Ministry of Health and Social Care authorized Hard Cole Mine „Dębieńsko” in Leszczyny for producing medicine called „Dębieńska Saline Multi-ingredient for Baths"[19], of below mentioned composition (unit in the $\mathrm{kg}$ (not $\mathrm{m}$ ) according to analysis [19]):

- $\quad$ solid substances dissolved in $1 \mathrm{~kg} 250$ to $300 \mathrm{~g}$,

- sodium $5,0 \%$ min.,

- magnesium $1,9-2,5 \%$,

- potassium $0,8-1,4 \%$,

- chlorides $16,0 \% \mathrm{~min}$.,

- bromides $0,10 \%$ min.,

- iodides $0,018 \% \mathrm{~min}$.

Registration certificate for above mentioned medicine has been published in April 1985 by the Ministry of Health and Social Care.

The highly mineralized Zabłocka brine contains up to 38 $\mathrm{g}$ of solids in $1 \mathrm{~kg}$, including (unit in the $\mathrm{kg}$ (not $\mathrm{m}$ ) according to analysis [20]):

- $\quad$ iodides $120 \mathrm{mg} / \mathrm{kg}$

- bromides $160 \mathrm{mg} / \mathrm{kg}$

- $\quad$ chlorides $23,000 \mathrm{mg} / \mathrm{kg}$

- $\quad$ magnesium $516 \mathrm{mg} / \mathrm{kg}$ 


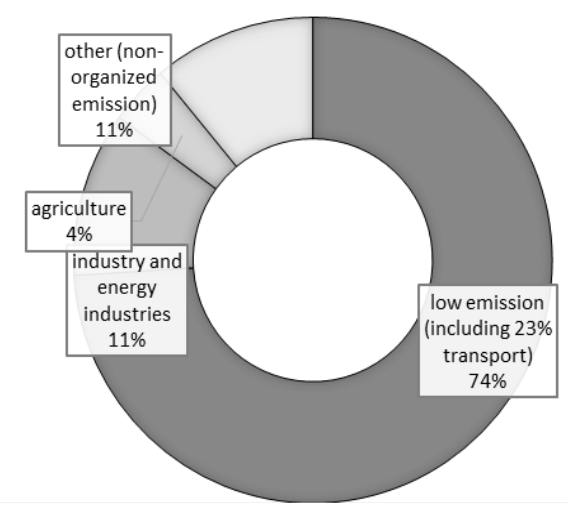

Fig. 7. Sources of PM10 dust particle emissions in the Silesia according to [28] Rys. 7. Źródło emisji pyłów PM10 na Górnym Śląsku według [28]

- $\quad$ potassium $86.5 \mathrm{mg} / \mathrm{kg}$

- $\quad$ sodium $13100 \mathrm{mg} / \mathrm{kg}$

Other minerals not included in the above list are calcium, iron, strontium, silicates, bicarbonates, and sulfates.

Based on the comparative analysis of different brines available on the market, the Dębieńsko brine was found to be highly mineralized. The share of solids in $1 \mathrm{~kg}$ of the Dębieńsko brine is ten times higher than the therapeutic iodine-bromine-boron brine commercially used for the production of cosmetics and supporting the treatment of many ailments [20].

The use of the Dębieńsko brine in medicine or in the production of cosmetics can additionally minimize the negative impact on the natural environment, because this brine can be obtained by exploiting salt mine waters, thus limiting their discharge into rivers.

On the basis of mining saline, in Leszczyny, close to mine „Dębieńsko” and Desalination Plant, in the middle of 80. was established balneological clinic, where with success was practiced big offer of water healing procedures intended for mine employees and for outside interested. Unfortunately liquidation in the end of 1999 of Hard Cole Mine „Dębieńsko” settled about future of this clinic. Despite of the fact that demand for that kind of healing procedures was and is very high financial causes decided about its final liquidation in 2003 and creating in the same building balneological clinic and therapeutic workshops for handicapped children. Lack of support from National Fund of Health (NFZ) or local authorities decided about future of this institution.

Currently Dębieńskie Saline are waste during salt production in Desaltination Plant Dębieńsko. What makes Dębieńskie saline special is very high level of saturation with iodine, about 120 to $140 \mathrm{mg} / \mathrm{l}$. For comparison Bałtyk, sea with high salinity has got about $6 \mathrm{mg} / \mathrm{l}$. Healing values of Dębieńskie Saline and it's easy availability are important useful value of this product for promotion of new product not only healing one but also touristic one.

Good example created together by authorities of Commune Czerwionka-Leszczyny and Desalination Plant Dębieńsko could be for the beginning recreational - holiday place with natural inhalator place in the shape of very popular in Poland and in the world fountain "mushroom". Being in surrounding of such object brings not only relaxation effects but most of all healing effects. Such installations are placed among all others in Ciechocinek, Inowrocław, Konstancin Zdrój, Dąbki, in many water parks, but also in Germany, Czech Republic, and Hungary (Fig.3.).

Saline that fall from the base of the object is evaporating and creating special micro climate and is additionally breaks in mechanical way by the mushroom and creating spray. Minerals and micro elements which are in saline are being absorbed by mucosal membrane of respiratory tract and skin and complete lack of those elements in human body. Healing action of saline is having good influence on nervous system, system of endocrine glands and for general immunity of system.

Saline can be also used in saline bed - pans located by the recreation centers, as it is for example in Aqua Park in Tarnowskie Góry. Fashion for healthy life style, forces local authorities to create indoor swimming pools fully equipped. Using in them saline from Dębieńsko is possible when brochure will be elaborated, offers which promotes healing values supported by medical and cosmetology authority. For popularization of those values can be used various electronic and printed media. One of the target groups, to which those recreation services will be directed to are families with children from surroundings of Rybnik, Tychy, Mikołów, Katowice (Fig.5.) or Chorzów.

Almost in every city as, nomen omen, „spring up like mushrooms" Saline Caves. Despite relatively high fees for entering they have big market for their services. Iodium concentration in Caves is incomparably lower than concentration Dębieńska Saline. That's why need for such service would probably be huge. Of course assuring proper gastronomical and rest infrastructure would enrich the offer and encourage visiting this place. Therefore it is necessary to activate development of MSP in the Commune. That kind of companies determine about fast developing of the region.

Interesting form of gaining funds for investments of area recultivation and creating recreation areas can be funds from UE. More interesting one are now RPO and ETC.

Regional Operational Program for Silesian District contains many actions priorities. They have been defined based on approved RPO targets. For those belong, among others:

- Increase of touristic competitiveness of the region; 
- $\quad$ Protection and improvement of environment;

- Sustainable development of cities;

- Improving health state of region inhabitants.

They fit perfectly to proposed solutions and investments in Czerwionka-Leszczyny.

The use of mine waste, such as brines from underground waters, should be a source of inspiration for the search for opportunities to transform apparent losses into possible profits - if not economical, then certainly environmental. The analysis of strengths and weaknesses of mining waste utilization is presented in the SWOT matrix (Fig. 6.).

According to the authors, the biggest threat to the lack of activities and pro-ecological use of post-mining waste is the poor perception of mining plant operations in the Silesian Voivodeship. Heavy dust, mining damage and low emissions are responsible for bad publicity for Polish mines. The management boards of coal companies devote too little attention to greater pro-ecological diversification of activities. The inspiration for these plants should be the growing industry of waste recycling, which is an increasingly better source of income. Mining plants should base their activities on the principles of circular economy. Not only will this allow them to change their image, but also to search for additional, although currently small, sources of income.

\section{Summary}

The problem with low emissions is currently a big problem for the inhabitants of the Silesian Voivodeship. Local emissions are the source of threats to air quality around the world. This is particularly true with regards surface, point or linear sources. At the same time, with growth in population density, the amount of waste or increases in energy demand, all have a major impact on air quality. In addition to social and health effects, financial effects are important from an economic point of view. Therefore, the fight against smog must begin at the level of local authorities, primary education and promotional activities addressed directly to the public [22] Of course, even the best laws cannot replace changes in attitudes and behaviours. In the Silesian Voivodeship over the past decade or so, the focus has been on reducing emissions from particularly burdensome factories and plants [23].

This emission was effectively limited. The problem of smog, however, remained. Currently, the major sources of particulate matter, in this region, include low emissions from the individual furnaces and transport wheels (Fig.7.) [24]. The World Health Organization draws attention to PM10 and PM2.5 as well as carcinogenic compounds that are released during incomplete combustion of low quality carbon fuels $[25,26]$.

Air pollution generates costs associated with treatment, absence from work or premature death. According to WHO estimates, the effects of air pollution in Poland are a cost of around 13\% of GDP [27].

Problems with low emissions are the reason for seeking improvements in living conditions and ways of recreation for the inhabitants of the Silesian Metropolis. Small graduation towers built in small parks or squares are becoming more and more popular. Strongly ionized air is available "at your fingertips." Expensive brines from Polish health resorts are brought to the increasingly popular brine graduation towers. Nobody searches for or can see other cheaper sources. Sometimes, post-industrial waste can become an opportunity for the Silesian region. Obviously, up-to-date documentation and modernization of desalination technology is necessary, but due to the increasing demand for graduation towers and brines, such a profile of the use of saline mine waters is justified.

In the summary of this article it is worth to mention that only selected possibilities of enriching list of development of diversificated offer of polish hard coal mine works from Upper Silesia opportunities were presented. Works conducted in this direction by local authorities, mine works management, by Research Institutes which shows possibilities of transformations which are already realized and directions of transformations in future. Especially currently in the era of leaving style of consumption society and going to resource - sparing society those are important tasks for the future. From the opportunities which we will use or not, next generation will report back. 


\section{Literatura - References}

1. Rostański, A. Kształtowanie się spontanicznej pokrywy roślinnej na terenie zwałowisk poprzemysłowych w aglomeracji katowickiej, Publisher of Silesian University, Katowice 2006.

2. Halecki, W.; Klatka, S. Long term growth of crop plants on experimental plots created among slag heaps, Ecotoxicol Environ Saf. 2018 Jan, 147, 86-92.

3. http://pl.wikipedia.org/wiki/Halda_win Rydultowach, 25/03/2020.

4. Korski, J.; Henslok, P.; Bodynek. P, Doświadczenia z likwidacji zapożarowania składowiska odpadów powęglowych "skalny" w Łaziskach Górnych, Magazine of Silesian University of Technology (Zeszyty naukowe s. Górnictwo) 2004, 261, 463-474 .

5. Wasilewski, S. Skotniczny, P. Mining waste dumps - modern monitoring of thermal and gas activities, Gospodarka Surowcami Mineralnymi 2015, T. 31, z. 1, 155-181.

6. https://www.mszana.ug.gov.pl/, 25/03/2020.

7. Pancewicz, A. Hałdy- kłopot czy szansa? Nauka Przyroda Technologie. Uniwersytet Przyrodniczy w Poznaniu 2009, $03,1,1-6$.

8. Pusz, A.; Rogalski, D.; Trawińska, A. Chemical Degradation and Processes of Erosion of Post-Mine Territories After Mining Exploration of Iron Ore, Journal of Ecological Engineering 2017, Vol. 18, 6, 71-79.

9. Balcombe, P.; Speirs, J.F.; Brandon, N.P.; Hawkes, A.D. Methane emissions: Choosing the right climate metric and time horizon, Environ. Sci. Process. Impacts 2018, 20, 1323-1339.

10. Malinowski, D. Metan wciąż do wzięcia, www.wnp.pl 2008, 16/04/2020.

11. Dudała, J. JSW: metan na celowniku, www.wnp.pl 2019, 16/04/2020.

12. Łukaszczyk, Z. Pozyskiwanie i gospodarcze wykorzystanie metanu za zlikwidowanych kopalń węgla kamiennego, Wyd. Politechniki Śląskiej, Gliwice 2019.

13. Grzybek, I. Przegląd technologii pozyskania metanu ze zlikwidowanych kopalń węgla w Polsce, Bezpieczeństwo Pracy i Ochrona Środowiska w Górnictwie 2017, 10, 31-37.

14. Skorek, J.; Kalina, J.; Backhaus, C.; Mroz, A. Możliwości wykorzystania metanu z pokładów węgla w niemieckich i polskich kopalniach, Zeszyty Naukowe. Cieplne Maszyny Przepływowe - Turbomachinery, Politechnika Łódzka 2004, 125, 227-242.

15. Date of WUG, available online http://www.wug.gov.pl/bhp/stan_bhp_w_gornictwie, 22/03/2020.

16. Koszera, D. , Biały, W., Doświadczenia z wykorzystaniem metanu na przykładzie kopalni węgla kamiennego, Systemy Wspomagania w Inżynierii Produkcji 2012, z. 2 (2), 121-132.

17. Andrusikiewicz W.; Żyromski Z., Ograniczanie negatywnego wpływu słonych wód dołowych na środowisko na przykładzie KWK Silesia, Gospodarka Surowcami Mineralnymi, 2003, t. 19 spec. iss., s. 75-84

18. Ponikowska, I. Utilization of dębieńska saline in therapeutics, PZH Poznań, 1985.

19. Registration Certificate of Medicine no. 1397, Ministry of Health and Social Care 30/04/1985

20. http://zablocka.pl/pl/produkt/mgielka-solankowa, 27/04/2020.

21. http://www.solanki.pl/pl/teznie-i-park, 11/05/2020.

22. Tobór-Osadnik, K. Local government policy in the Silesian province with regards to a low-carbon economy, IOP Conf. Ser.: Earth Environ. Sci. 2019, Vol. 261, 012054.

23. Łukaszczyk, Z. Węgiel tak, smog nie - świadomość i odpowiedzialność, Systemy wspomagania w inżynierii produkcji. Górnictwo - perspektywy, zagrożenia. Węgiel, tania czysta energia i miejsca pracy 2018, vol 7, 484-96.

24. Janssen, N. A. H.; Gerlofs-Nijl, M. E.; Lank, T.; Salonen, R. O.; Cassee, F.; Hoek, G.; Fischer, P.; Brunekreef, B.; Krzyżanowski, M. Health effects of black carbon (Copenhagen: Publisher WHO Regional Office for Europe) 2012.

25. Kurczabiński, L. Węgiel kamienny w sektorze komunalno - bytowym, VII Ekoenergetyczna konferencja - Aktywizacja gminy za pomocą innowacyjnej energetyki rozproszonej, materiały konferencyjne, Gliwice 2010, 6-10.

26. Stala-Szlugaj, K. Spalanie węgla kamiennego w sektorze komunalno-bytowym - wpływ na wielkość „niskiej emisji”, Środkowo-pomorskie towarzystwo naukowe ochrony środowiska, Rocznik Ochrona Środowiska 2011, 13, 1877 - 1889.

27. Zanieczyszczenie powietrza: przedwczesne zgony i duże koszty, serwis informacyjny CIRE 24, https://www.cire.pl/ item,104036,1,0,0,0,0,0,zanieczyszczenie-powietrza-przedwczesne-zgony-i-duze- koszty.html, 18/04/2020.

28. Date of KOBiZE (Krajowy Ośrodek Bilansowania i Zarządzania Emisjami), https://www.kobize.pl/, 04/01/2020. 


\section{Produkcja odpadów z kopalń wegla kamiennego w świetle Circular Economy}

Zakłady górnicze stoja przed zadaniem poszukiwania zmiany wizerunku przy jednoczesnym dodatnim wyniku ekonomicznym. Odpady pokopalniane moga stanowić szansę wdrożenia idei Circular Economy przez przedsiębiorstwa górnicze. W artykule autorki zaprezentowały przeglad kilku najważniejszych odpadów, takich jak hałdy, metan czy wody kopalniane. Analiza składu solanek uzyskiwanych w Zakładach „Debieńsko” pozwolita sformułować liczne wnioski ich nowego wykorzystania. Zanieczyszczenie powietrza, a zarazem zwiększone potrzeby prozdrowotne społeczeństwa pozwalaja sądzić, że otwieraja się nowe możliwości proekologicznego i rekreacyjnego wykorzystania tego co do tej pory stanowiło o złym postrzeganiu przemysłu wegla kamiennego na Górnym Ślasku. $W$ artykule zaproponowano szereg rozwiazań $w$ tym obszarze.

Słowa kluczowe: kopalnie węla kamiennego, odpady, hałdy, solanki, metan 